\title{
Evaluation of Possible Surrogates for Validation of the Oxidation Furnace for the Plutonium Disposition Project
}

\author{
Andrew J. Duncan \\ Savannah River National Laboratory \\ Washington Savannah River Company
}

Publication Date: January, 2008

\section{Washington Savannah River Company Savannah River Site Aiken, SC 29808}

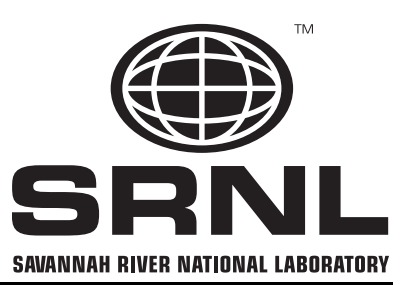

This document was prepared in connection with work done under Contract No. DE-AC09-96SR18500 with the U. S. Department of Energy 


\section{DISCLAIMER}

This report was prepared as an account of work sponsored by an agency of the United States Government. Neither the United States Government nor any agency thereof, nor any of their employees, makes any warranty, express or implied, or assumes any legal liability or responsibility for the accuracy, completeness, or usefulness of any information, apparatus, product, or process disclosed, or represents that its use would not infringe privately owned rights. Reference herein to any specific commercial product, process, or service by trade name, trademark, manufacturer, or otherwise does not necessarily constitute or imply its endorsement, recommendation, or favoring by the United States Government or any agency thereof. The views and opinions of authors expressed herein do not necessarily state or reflect those of the United States Government or any agency thereof. 
DOCUMENT: $\quad$ WSRC-TR-2007-00471, Rev. 0

TITLE: Evaluation of Possible Surrogates for Validation of the Oxidation Furnace for the Plutonium Disposition Project

\section{APPROVALS}

A.J. Duncan, Author

Date:

SRNL-MATERIALS SCIENCE \& TECHNOLOGY

Materials Applications \& Process Technology Group

John H. Scoggins, IV, Technical Review

Date:

SRNL-ACTINIDE CHEMICAL TECHNOLOGY

Actinide Science Programs

R. L. Sindelar, Manager

Date:

SRNL-MATERIALS SCIENCE \& TECHNOLOGY

Materials Applications \& Process Technology Group

N.C. Iyer, Director

Date:

SRNL-MATERIALS SCIENCE \& TECHNOLOGY 


\section{Table of Contents}

$1.0 \quad$ Introduction.

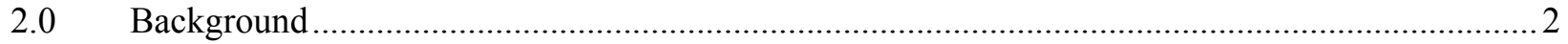

3.0 Characteristics of Plutonium and ITS Oxide Interface ........................................................... 4

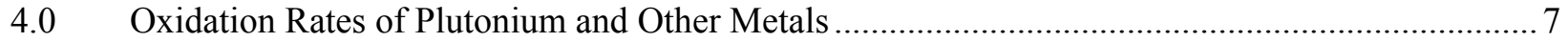

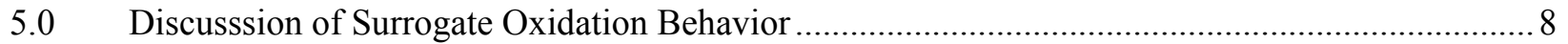

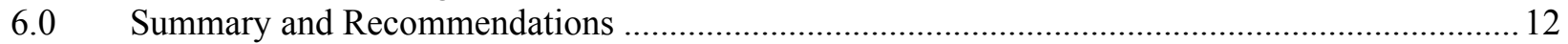

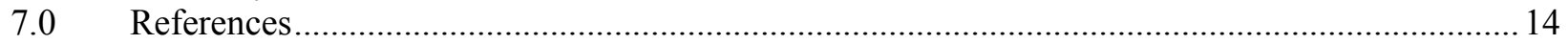

\section{List of Figures}

Figure 1: Schematic representation of metals oxidation: (a) adsorption of oxygen molecule, (b) dissociation of adsorbed oxygen molecule, (c) continued growth by diffusion of oxygen and metal ions through oxide and (d) development of an outer porous layer at the oxide-gas interface and oxygen anion diffusion through it. ${ }^{2}$

Figure 2: Oxidation kinetics observed for oxidation of metals: (a) power law and linear fit of oxidation behavior and (b) a pseudo-linear rate as described in Figure $1 .{ }^{2}$

Figure 3: Schematic of the $\mathrm{CaF}_{2}$ structure which is the basis for oxide phases in the plutonium-oxide

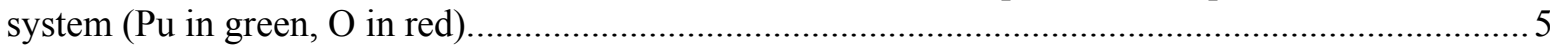

Figure 4: Arrhenius Curves for Oxidation of Plutonium in Dry Air (curve 1) and Water Vapor (curve 2a, $\mathrm{b}$ and c). Gallium containing delta phase curves are denoted by the 1' and 2' labels. Curve 3 between $400^{\circ} \mathrm{C}$ and $500^{\circ} \mathrm{C}$ denotes the temperature range where the previous rates converge, prior to auto-ignition ${ }^{3}$.

ure 5: Oxidation Rates of Various Metals in Dry Air or Oxygen Compared to Plutonium (oxidation rate normalized for density of metallic substrate) ..................................................................... 11

Figure 6: Effect of alloying addition on oxidation rate of zirconium (from Schnizlein et al.) the published rate for $3.6 \% \mathrm{Sn}$ is $292 \times 10^{-6} \mathrm{~g} / \mathrm{cm} 2 / \mathrm{min}$ at $700{ }^{\circ} \mathrm{C}$ which is roughly equivalent to $\mathrm{Pu}$ at $400{ }^{\circ} \mathrm{C} \ldots . .12$

\section{List of Tables}

Table I: Compiled Table of Metal-Oxide Systems to be Evaluated as Potential Surrogates for Pu Oxidation Studies 6

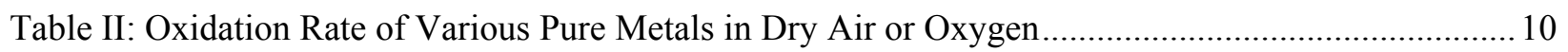

Table III: Summary of Potential Surrogates for Plutonium Oxidation .................................................... 13 
WSRC-TR-2007-00471, Rev. 0

\subsection{INTRODUCTION}

The Plutonium Disposition project $(\mathrm{PuD})$ is considering an alternative furnace design for direct metal oxidation (DMO) of plutonium metal to use as a feed for potential disposition routes. The proposed design will use a retort to oxidize the feed at temperatures up to $500 \mathrm{C}$. The atmosphere will be controlled using a metered mixture of oxygen, helium and argon to control the oxidation at approximately 400 torr. Since plutonium melts at $664 \mathrm{C}$, and may potentially react with retort material to form a lower melting point eutectic ${ }^{1}$, the oxidation process will be controlled by metering the flow of oxygen to ensure that the bulk temperature of the material does not exceed this temperature. A batch processing time of $<24$ hours is desirable to meet anticipated furnace throughput requirements..

The design project includes demonstration of concept in a small-scale demonstration test (i.e., small scale) and validation of design in a full-scale test. These tests are recommended to be performed using Pu surrogates due to challenges in consideration of the nature of plutonium and operational constraints required when handling large quantities of accountable material. The potential for spreading contamination and exposing workers to harmful levels of cumulative radioactive dose are motivation to utilize non-radioactive surrogates. Once the design is demonstrated and optimized, implementation would take place in a facility designed to accommodate these constraints. Until then, the use of surrogates would be a safer, less expensive option for the validation phase of the project.

This report examines the potential for use of surrogates in the demonstration and validation of the DMO furnace for PuD. This report provides a compilation of the technical information and process requirements for the conversion of plutonium metal to oxide by burning in dry environments. Several potential surrogates were evaluated by various criteria in order to select a suitable candidate for large scale demonstration. First, the structure of the plutonium metal/oxide interface was compared to potential surrogates. Second the data for plutonium oxidation kinetics were reviewed and rates for oxidation were compared with surrogates. The criteria used as a basis for recommendation was selected in order to provide a reasonable oxidation rate during the validation phase. Several reference documents were reviewed and used to compile the information in this report. Since oxidation of large monolithic pieces of plutonium in $75 \%$ oxygen is the preferable oxidizing atmosphere for the intended process, this report does not focus on the oxidation of powders, but focuses instead on larger samples in flowing gas. 


\subsection{BACKGROUND}

The oxidation reaction of a metal (e.g., plutonium) with oxygen, $\mathrm{O}_{2}$, is the sum of several separate reactions occurring simultaneously ${ }^{2}$. These include the dissociation of $\mathrm{O}_{2}$, oxidation and reduction of the valence states of the metal and oxygen, respectively and combination of the individual elements into an oxide compound. For the case of a metal, Me, with valence, n, reacting with oxygen, $\mathrm{O}_{2}$, the reactions are:

$$
\begin{aligned}
& \text { Dissociation: } \mathrm{O}_{2} \stackrel{\mathrm{Me}}{=}=2 \mathrm{O} \\
& \text { Oxidation: } \mathrm{Me}=>\mathrm{Me}^{\mathrm{n}+}+\mathrm{ne}^{-} \\
& \text {Reduction: } \mathrm{n}_{/ 2}\left(\mathrm{O}+2 \mathrm{e}^{-}=>\mathrm{O}^{2-}\right) \\
& \text { Combination: } 2 \mathrm{Me}^{\mathrm{n}^{+}}+\mathrm{n} \mathrm{O}^{2-}=>2 \mathrm{MeO} \mathrm{n} / 2
\end{aligned}
$$

The resultant oxide film created is energetically favorable to the metal. When this happens, energy is given off in the form of heat, which raises the temperature of the metal and its surroundings. The phenomenon of oxidation occurs, mechanistically, in several steps. These steps are shown schematically in Figure 1 (a-d). Initially, adsorption of the oxidizing molecule (Figure 1 a) to the surface of the metal starts the reaction, followed by its dissociation and ionization (Figure $1 \mathrm{~b})$. Metal cations $\left(\mathrm{Me}^{\mathrm{n}+}\right)$ combine with the oxygen anions $\left(\mathrm{O}^{2-}\right)$ to form oxide. The potential difference created by the charge transfer and concentration gradients in the oxide layer drive ion migration and growth of the oxide film (Figure 1c). Subsequent oxygen molecule adsorption occurs on the oxide surface, followed by dissociation and ionization. The oxygen ions, metal ions or both move through the oxide by diffusion to combine with the other species and form more oxide. As the oxide grows, the potential difference and concentration gradients become negligible as thickness increases, reducing the driving force for oxide film growth. However, mechanical stress develops in the oxide layer as it thickens, due to volumetric discontinuity. The different densities of the oxide and metal structures result in an interfacial mismatch and an induced stress in the oxide. As the oxide film grows, the stress increases and may become large enough to cause fracture and lead to the formation of a porous, non-protective layer. In some systems, the stress becomes large enough to cause the oxide to spall away.

As long as the oxide remains adherent and protective, the oxidation rate decreases with time and eventually becomes very small. This is often due to diffusion of ionic species through the oxide film, which is a key mechanism controlling the rate by which the film grows. In the case of plutonium, the diffusion of metal ions through the oxide is negligible, so growth is controlled by $\mathrm{O}^{2-}$ diffusion. This behavior is usually best represented by a parabolic law fit of the relationship between weight gain (W) and time ( $\mathrm{t}$ ), $\mathrm{W}^{2}=\mathrm{kt}$ When the oxide is porous or cracks due to high stress, open pathways allow movement of the oxidizing species and the oxidation rate tends to approach a constant with time (i.e., linear relationship, $\mathrm{W}=\mathrm{kt}$ ). In Figure $2 \mathrm{a}$, a graphic representation is shown for parabolic or linear behavior. If the oxide growth is modeled by a parabolic relationship which is reinitiated from time to time due to spallation of the protective film, the result is a pseudo-linear relationship, which is shown in Figure $2 b$. Regardless of the form of the equation used to represent the reaction, the rate constant k usually exhibits an Arrhenius relationship with temperature as in the following equation:

$$
\begin{aligned}
& \mathrm{k}=\mathrm{A} \exp (-\mathrm{Q} / \mathrm{R} * \mathrm{~T}) \text { where } \mathrm{k}=\text { oxidation rate constant } \\
& \mathrm{A}=\text { frequency factor } \\
& \mathrm{Q}=\text { the activation energy } \\
& \mathrm{R}=\text { gas constant } \\
& \mathrm{T}=\text { absolute temperature }
\end{aligned}
$$




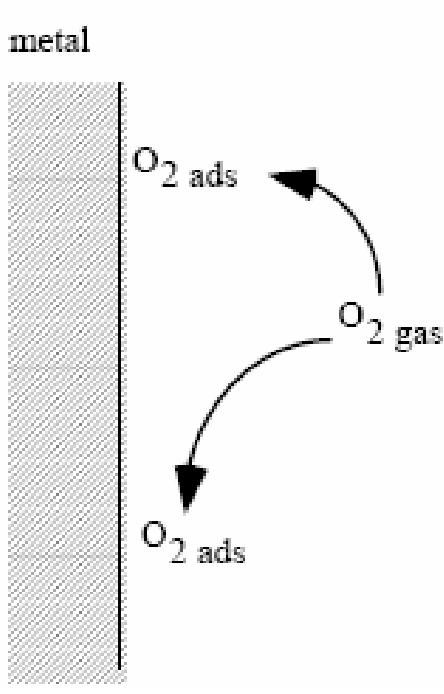

(a)

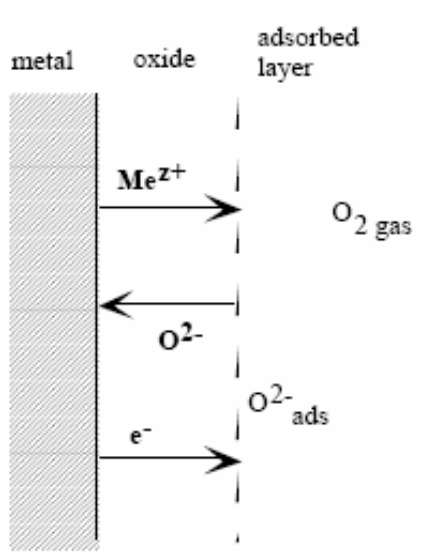

(c)

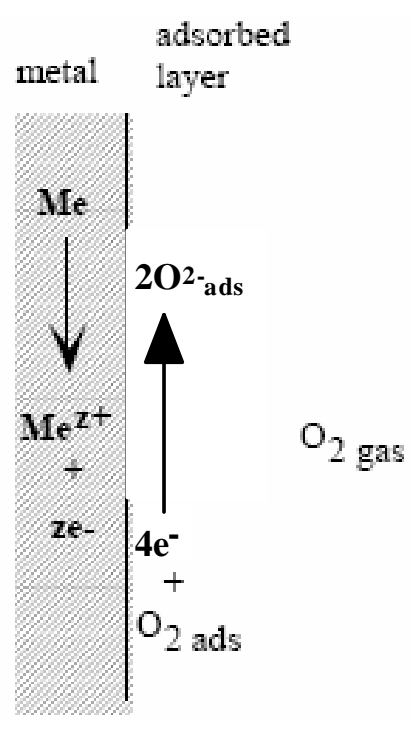

(b)

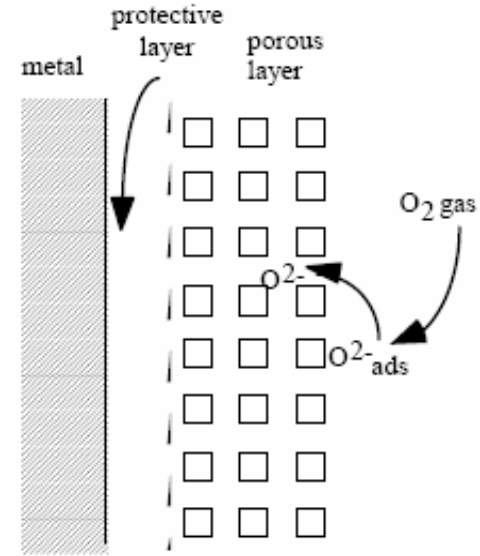

(d)

Figure 1: Schematic representation of metals oxidation: (a) adsorption of oxygen molecule,

(b) dissociation of adsorbed oxygen molecule, (c) continued growth by diffusion of oxygen and metal ions through oxide and (d) development of an outer porous layer at the oxide-gas interface and oxygen anion diffusion through it. ${ }^{2}$ 


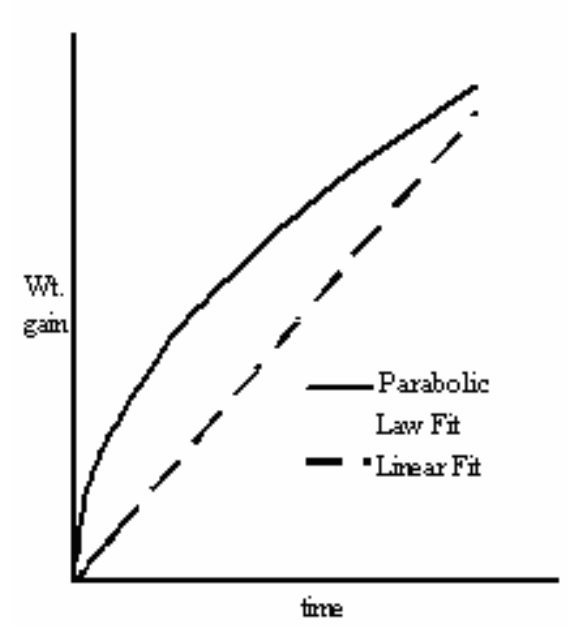

(a)

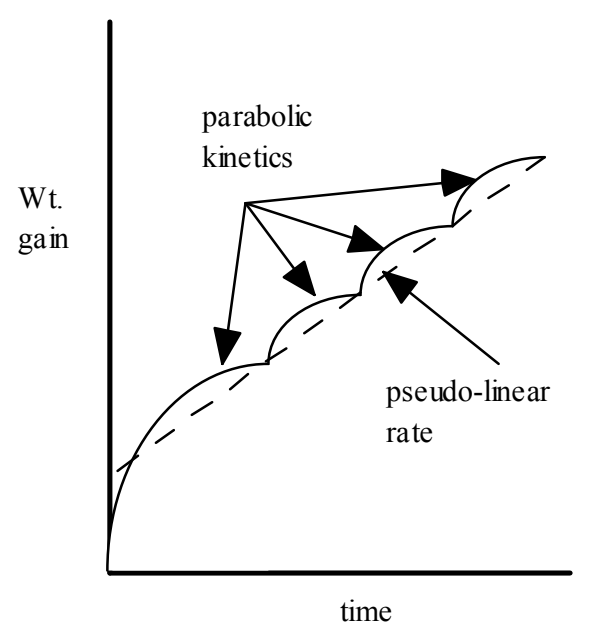

(b)

Figure 2: Oxidation kinetics observed for oxidation of metals: (a) power law and linear fit of oxidation behavior and (b) a pseudo-linear rate as described in Figure 1. $^{2}$

\subsection{CHARACTERISTICS OF PLUTONIUM AND ITS OXIDE INTERFACE}

Plutonium metal will oxidize readily at near ambient to intermediate temperatures, and can be pyrophoric depending on particle size and other factors ${ }^{3}$. However, for large pieces, the oxide can be protective and effectively halt the oxidation process. Various stoichiometries exist for the oxide; the composition of which is largely dependent on temperature and oxygen concentration. In an oxygen rich atmosphere, the primary oxide phase is observed to be $\mathrm{PuO}_{2}$, but other intermediate stoichiometries are also observed. The oxide structure is based on the $\mathrm{CaF}_{2}$ structure (See Figure 3), which is a face centered cubic lattice with cations (i.e., $\mathrm{Pu}$ ) at corners and faces of the unit cell and anions at tetrahedral sites (i.e., O). Ordered vacancies on $25 \%$ of the anion sites occupied by oxygen produce a different stoichiometry of oxide (i.e., $\mathrm{Pu}_{2} \mathrm{O}_{3}$ ) ${ }^{4} \mathrm{PuO}_{2}$ is the most stable form of the oxide at ambient temperature, but the $\mathrm{Pu}_{2} \mathrm{O}_{3}$ exists at the metal/oxide interface and at low oxygen partial pressures. Other phases (i.e., $\mathrm{PuH}_{2}, \mathrm{PuOH}$ and $\mathrm{PuN}$ ) have been observed to form as a result of reactions between $\mathrm{Pu}$ and water or other atmospheric gases. However, the proposed process will be using mixtures of argon, helium and oxygen so the formation of these phases is not discussed here.

Table I contains the properties of interest for plutonium and other metal/oxide systems. One indicator of how protective the surface oxide film will be during high temperature oxidation is known as the Pilling-Bedworth Ratio. The Pilling-Bedworth ratio (P-B ratio) of a metal oxide is defined as the ratio of the volume of the metal oxide, which is produced by the reaction of metal and oxygen, to the consumed metal volume. When a P-B ratio is less than 1, a metal oxide tends to be porous and non-protective because it cannot cover the whole metal surface. When a P-B ratio is excessively large, large compressive stresses are likely to exist in metal oxide, leading to buckling and spalling. It is evident from Table 1 that the stresses at the metal/oxide interface for both phases of plutonium are compressive in nature and should be protective. By comparison $\mathrm{U} / \mathrm{UO}_{3}$ has a higher $\mathrm{P}-\mathrm{B}$ ratio which may indicate high compressive stresses at temperatures that favor $\mathrm{UO}_{3}$ formation.

In addition to P-B ratio, factors such as the heat of formation of the oxide and thermal diffusivity of the substrate can affect the rate at which the interfacial heats during the oxidation 
reaction. Heat is usually carried away from the interface through the substrate and low thermal diffusivities will cause the metal oxide interface to heat up faster and increase the rate of reaction. Other factors, such as relative coefficients of thermal expansion and the adherence between metal oxide and metal can play a role but have been neglected here.

Plutonium's $\delta$-phase $/ \mathrm{PuO} 2$ system exhibits a reasonable $\mathrm{P}-\mathrm{B}$ ratio and is similar to metal oxide systems such as $\mathrm{Ni} / \mathrm{NiO}$ so the oxide scale is potentially protective. However, the heat of formation of $\mathrm{PuO} 2$ oxide, and the metal's low thermal diffusivity suggest that its scale is less protective than the $\mathrm{Ni} / \mathrm{NiO}$ interface. Uranium, titanium, hafnium, zirconium and cerium all have thermal diffusivities that approach that of $\mathrm{Pu}$ and their oxides have large heats of formation. This is one indicator of the potential for these metals to be effective surrogates for Pu during oxidation validation and demonstration runs.

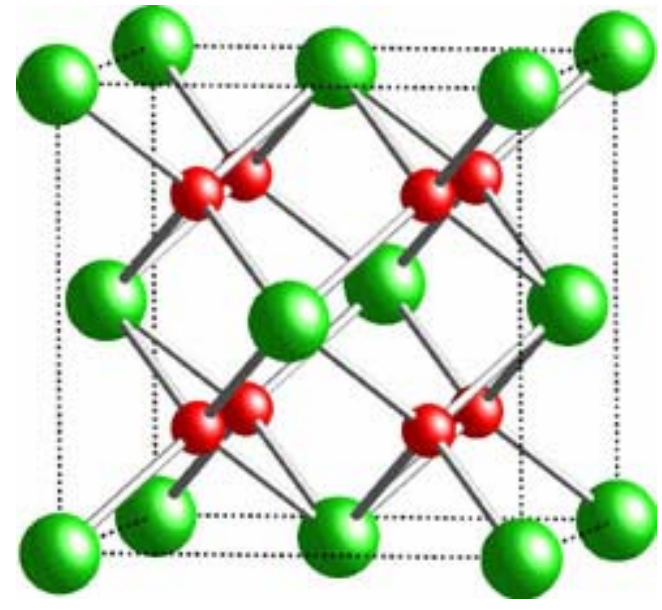

Figure 3: Schematic of the $\mathrm{CaF}_{2}$ structure which is the basis for oxide phases in the plutonium-oxide system (Pu in green, $\mathrm{O}$ in red). 
Table I: Compiled Table of Metal-Oxide Systems to be Evaluated as Potential Surrogates for Pu Oxidation Studies.

\begin{tabular}{|l|c|c|c|l|}
\hline \multicolumn{1}{|c|}{ Metal } & $\begin{array}{c}\text { Thermal } \\
\text { Diffusivity } \\
\left(\mathrm{cm}^{2} / \mathrm{sec}\right)\end{array}$ & $\begin{array}{c}\text { Pilling- } \\
\text { Bedworth } \\
\text { Ratio }\end{array}$ & $\begin{array}{c}\text { Heat of } \\
\text { Formation } \\
(\mathrm{kJ} / \mathrm{mole} \\
\text { metal })\end{array}$ & \multicolumn{1}{|c|}{ Oxide } \\
\hline $\mathrm{Pu}$ (delta) & 0.041 & 1.59 & -1050.9 & $\mathrm{PuO}_{2}$ \\
\hline $\mathrm{Pu}$ (delta) & 0.041 & 1.7 & -1050.9 & $\mathrm{Pu}_{2} \mathrm{O}_{3}$ \\
\hline $\mathrm{Pu}$ (alpha) & 0.024 & 1.98 & $\mathrm{PuO}_{2}$ \\
\hline $\mathrm{Pu}$ (alpha) & 0.024 & 2.12 & -266.7 & $\mathrm{PeO}$ \\
\hline $\mathrm{Fe}$ & 0.802 & 1.77 & -244.5 & $\mathrm{NiO}$ \\
\hline $\mathrm{Ni}$ & 0.229 & 1.70 & -239.5 & $\mathrm{CoO}$ \\
\hline $\mathrm{Co}$ & 0.267 & 2.0 & -155.3 & $\mathrm{CuO}_{3}$ \\
\hline $\mathrm{Cu}$ & 1.171 & 1.74 & -912.7 & $\mathrm{TiO}_{2}$ \\
\hline $\mathrm{Ti}$ & 0.093 & 1.78 & -1081.0 & $\mathrm{ZrO}_{2}$ \\
\hline $\mathrm{Zr}$ & 0.125 & 1.55 & -949.75 & $\mathrm{Nb}_{2} \mathrm{O}_{5}$ \\
\hline $\mathrm{Nb}$ & 0.236 & 2.67 & -544.3 & $\mathrm{MoO}_{2}$ \\
\hline $\mathrm{Mo}$ & 0.539 & 2.10 & -975.5 & $\mathrm{CeO}_{2}$ \\
\hline $\mathrm{Ce}$ & 0.087 & 1.17 & -1136.7 & $\mathrm{HfO}_{2}$ \\
\hline $\mathrm{Hf}$ & 0.120 & 1.62 & -1046.5 & $\mathrm{Ta}_{2} \mathrm{O}_{5}$ \\
\hline $\mathrm{Ta}$ & 0.247 & 2.47 & -570.7 & $\mathrm{WO}_{2}$ \\
\hline $\mathrm{W}$ & 0.683 & 2.10 & -1130.4 & $\mathrm{UO}_{2}$ \\
\hline $\mathrm{U}$ & 0.125 & 1.97 & -1191.6 & $\mathrm{U}_{3} \mathrm{O}_{8}$ \\
\hline $\mathrm{U}$ & 0.125 & 2.71 & -1223.8 & $\mathrm{UO}_{3}$ \\
\hline $\mathrm{U}$ & 0.125 & 3.14 & -1226.4 & $\mathrm{ThO}_{2}$ \\
\hline $\mathrm{Th}$ & 0.391 & 1.34 & & \\
\hline & & & & \\
\hline
\end{tabular}




\subsection{OXIDATION RATES OF PLUTONIUM AND OTHER METALS}

Since the early 1950's the oxidation reaction of metals like plutonium has been an area of interest for both process development and safety analysis. Most of the experiments were conducted on small samples exposed to heat in a radiant furnace. Oxidation rates were measured primarily in terms of $\%$ weight gain/time or weight gain/ (unit area $*$ unit time) which becomes problematic during oxidation for two reasons. First, the oxide film can often spall off the sample, and hence, it is difficult to accurately measure weight gain. Second, the stoichiometry of the oxide phase present affects the measured rate of oxidation. Finally, some confusion may exist in that rates are reported as mass $\mathrm{O}_{2} /$ unit area/unit time while others report mass of metal/unit area/unit time (mass metal $\sim 7.45 \mathrm{x}$ mass $\mathrm{O}_{2}$ for the $\mathrm{Pu}$ oxidation process). This being noted, data does exist for oxidation of $\mathrm{Pu}$ in moist and dry air over a range of temperatures.

The rate of oxidation also depends on several factors including temperature, environment, particle size and composition. At low temperatures, the oxidation of plutonium in air exhibits a parabolic relationship with time. As temperature is increased its oxidation behavior can be characterized in a linear or pseudo-linear fashion. Figure 4 is a depiction of the Arrhenius plot of oxidation rate as a function temperature for alloyed and unalloyed plutonium in dry air and water vapor by Haschke et al. ${ }^{3}$. Curves 1 and 2 refer to the rate of $\alpha$-plutonium in dry air and water vapor, respectively. Curves 1' and 2' are plutonium-gallium $\delta$-phase alloy in the respective environments. Curve 3 represents a transition from curves 1 and 2 to higher temperature behavior demonstrated by curves 4 and 5. Curve 4 describes autothermic oxidation above which temperature the reaction is self propagating and independent of temperature $(\mathrm{R}=0.14$ gram $\mathrm{Pu} / \mathrm{cm}^{2}$-min) without forced convection. This rate is controlled by the diffusion of oxygen through the boundary layer (rich in non-reactive gases) at the gas-solid interface. This is the maximum rate that can be expected under conditions of natural convection. Curve 5 is the free burning rate of small droplets falling in air, and is similar to this forced convection. The regime that the proposed process will operate in will most likely be governed by Curve 4 .

Oxidation of plutonium is a process that has been performed on laboratory and production scales for several years. Plutonium alloy oxidation was modeled for FB-Line furnaces for the stabilization of experimental reactor fuels. ${ }^{5}$ In addition, direct metal oxidation of plutonium metal is being demonstrated at Los Alamos in support of other programs. ${ }^{6}$ Both processes rely on the oxide layer spalling off on its own or being knocked off by tumbling to achieve the maximum oxidation rate. Thus, the process occurs at a temperature regime in which the oxide forms at a high rate and is non-protective. A suitable surrogate for plutonium would need to demonstrate both these characteristics at the temperature range in which it is oxidized.

Based on the information in Figure 4 and the candidates in Table I, oxidation rate information was compiled in Table $\mathrm{II}^{3,4,7,8,9,10,11,13 \text { and } 17}$. These metals may exhibit either a parabolic or a linear oxidation rate with time depending on temperature. One limitation to these results was that (with the exception of $\mathrm{Ta}$ and $\mathrm{Nb}$ ) all the oxidation data was compiled in air. The proposed oxidation process uses $75 \%$ oxygen and $25 \%$ helium, which would oxidize the materials at a higher rate, but should be consistent within the group. However, Ta and $\mathrm{Nb}$ values are for oxidation in a pure oxygen atmosphere, which would be higher than that for a helium-oxygen atmosphere. The rates constants were calculated from the rate equations in Table II and converted to $\mathrm{g}$ metal $/ \mathrm{cm}^{2} /$ unit time (if rates were not already in that form). Where the rate equations were not available, data was taken from the individual studies or published compilations. For a valid comparison, the oxidation was normalized by the density of the metal substrate to yield oxidation values of $\mathrm{cm} / \mathrm{hr}$.

The results are compiled in Figure 5 and are compared to values taken from curves 1, 1' and 4 in Figure 4. These curves should give a fair representation of the oxidation rate for plutonium 
in air or oxygen/inert gas mixtures. As can be seen from Figure 5, the autothermic burning rate of $\mathrm{Pu}$ oxidation is relatively high $(0.5 \mathrm{~cm} / \mathrm{hr})$. Although none of the proposed surrogates oxidize this quickly, several of them approach this burn rate at higher temperatures. In addition, smaller pieces (i.e., foil, wire, etc.) will yield higher oxidation rates and higher temperatures, if for no other reason than geometric constraint. For example, Leibowitz et al ${ }^{12}$ measured burning velocities of oxidation fronts in uranium and zirconium foils in air. They measured burn rates in air at temperature up to $2300^{\circ} \mathrm{C}$ in uranium and zirconium foils. Mouradian and Baker ${ }^{13}$ used the data to formulate a model for oxidation rates and burning temperatures of uranium and zirconium in natural and forced convection conditions for pieces up to $10 \mathrm{~cm}$ in diameter. The experimental data used to correlate these models, however, is based on much smaller samples. Other experimental studies ${ }^{11,17}$ have reported lower rates, than those predicted by Mouradian and Baker ${ }^{13}$ for uranium and zirconium, but clearly these materials have the closest rates to the autothermic burning rate for plutonium (curve 4) as described by Hascke et al. ${ }^{3}$ The values for uranium are plotted in Figure 5 for reference. The rate for uranium at $1000^{\circ} \mathrm{C}$ approached the value of $\mathrm{Pu}$ at $500^{\circ} \mathrm{C}$ and at $400^{\circ} \mathrm{C}$ exceeds the rate of $\delta$-Pu. Zirconium, tantalum and niobium exhibit the next highest oxidation rates, while thorium, hafnium and titanium are even lower.

\subsection{DISCUSSSION OF SURROGATE OXIDATION BEHAVIOR}

The character of the resulting oxide will determine whether surface is protected form further oxidation. In the case of parabolic rate constants, the oxide layer usually provides some form of protection, because it limits oxide growth by the diffusion of species through the oxide film. Some of the materials undergo what is referred to as breakaway oxidation, where after an initial parabolic behavior oxidation continues at a high linear rate.

Oxidation studies of uranium note that the oxide appearance is black fine powder that cracks and spalls away from the substrate in the range of 150 to $400^{\circ} \mathrm{C}$ and again at $650^{\circ} \mathrm{C}$ as temperature increases. ${ }^{14,17}$ The resulting oxide phases that are observed to form are $\mathrm{UO}_{2}$ (below $200{ }^{\circ} \mathrm{C}$ ) and/or $\mathrm{U}_{3} \mathrm{O}_{8}$ (above $\left.250{ }^{\circ} \mathrm{C}\right)^{14}$. Thorium's oxidation rate is much lower than uranium and the only oxide phase found is $\mathrm{ThO}_{2} .{ }^{8}$ Isothermal oxidation of both elements is marked by exothermic temperature spikes that occur when the oxide spalls away, exposing new material. ${ }^{8}$ This behavior is similar to that observed when plutonium is oxidized. ${ }^{4}$

Zirconium, hafnium and titanium all appear to exhibit some kind of breakaway phenomenon ${ }^{7}$. Zirconium and hafnium are observed to have tightly adherent oxide films until an initiation of breakaway oxidation which transforms its appearance to white fluffy. In both cases the oxide film is observed to be monoclinic- $\mathrm{ZrO}_{2}$ but could be an oxygen deficient stoichiometry.

Oxidation rate is said to be controlled to a large degree by the solubility of oxygen in $\alpha$-zirconium and the diffusion of oxygen through the scale. The onset of breakaway oxidation appears to be hastened by the presence of impurities and alloying additions which lead to discontinuities or cracking in the oxide scale. ${ }^{7}$ Schnizlein ${ }^{15}$ studied the oxidation of zirconium alloys and determined that alloying additions had a significant effect on the breakaway oxidation behavior. Additional studies have shown the accelerated rate at temperatures as low as $300{ }^{\circ} \mathrm{C}$. ${ }^{16}$ Figure 6 shows the affect of alloying addition of the oxidation behavior of zirconium at $700^{\circ} \mathrm{C}$. Relatively small amounts of tin, aluminum or titanium have a high rate oxidation after an initiation period. The oxidation behavior of hafnium has not been studied to the degree of zirconium and titanium but it is understood as being similar to zirconium (albeit at a lower rate). The oxide scale is composed of monoclinic $\mathrm{HfO}_{2}$ and exhibits the breakaway phenomenon similar to that of zirconium. ${ }^{8}$ Titanium also exhibits a lower rate of oxidation than that of zirconium but its oxide consists primarily of tetragonal (i.e., rutile) $\mathrm{TiO}_{2}$, although sometimes a porous subsurface layer of $\mathrm{TiO}, \mathrm{Ti}_{2} \mathrm{O}_{3}$ and $\mathrm{TiO}_{2}$ have been observed. ${ }^{8}$

Both tantalum and niobium exhibit regimes of breakaway oxidation. Tantalum and Niobium readily oxidize as low as $300{ }^{\circ} \mathrm{C}$. Above $500{ }^{\circ} \mathrm{C}, \mathrm{Ta}_{2} \mathrm{O}_{5}$ and $\mathrm{Nb}_{2} \mathrm{O}_{5}$ form readily on their 
respective substrates. ${ }^{7}$ Tantalum exhibits a regime between 600 and $800{ }^{\circ} \mathrm{C}$ that the rate of oxidation increases dramatically. Above $800^{\circ} \mathrm{C}$ the oxide scale on tantalum turns white and disintegrates. The oxidation rate of tantalum continues to increase gradually above this point. Niobium exhibits breakaway phenomenon between 500 and $650^{\circ} \mathrm{C}$, but above this point the scale appears to become protective. Its initial oxidation is more complex than tantalum due to the presence of transition oxide phases (i.e., $\mathrm{NbO}$ and $\left.\mathrm{NbO}_{2}\right)^{7}$. From 650 to $850{ }^{\circ} \mathrm{C}$ the oxidation rate is governed again by a parabolic relationship. Above $850{ }^{\circ} \mathrm{C}$ a high temperature form of $\mathrm{Nb}_{2} \mathrm{O}_{5}$ becomes predominant again that the oxidation rate becomes linear again. The overall rate of oxidation of niobium is similar to tantalum, above this point.

Cerium has a high rate of oxidation at low temperatures. Below its ignition point, oxidation rates in excess of that measured for $\alpha$-plutonium have been published. Unfortunately the ignition temperature $\left(\sim 350^{\circ} \mathrm{C}\right)$ is so low that oxidation studies would be impractical and experimental results would be non-conservative.

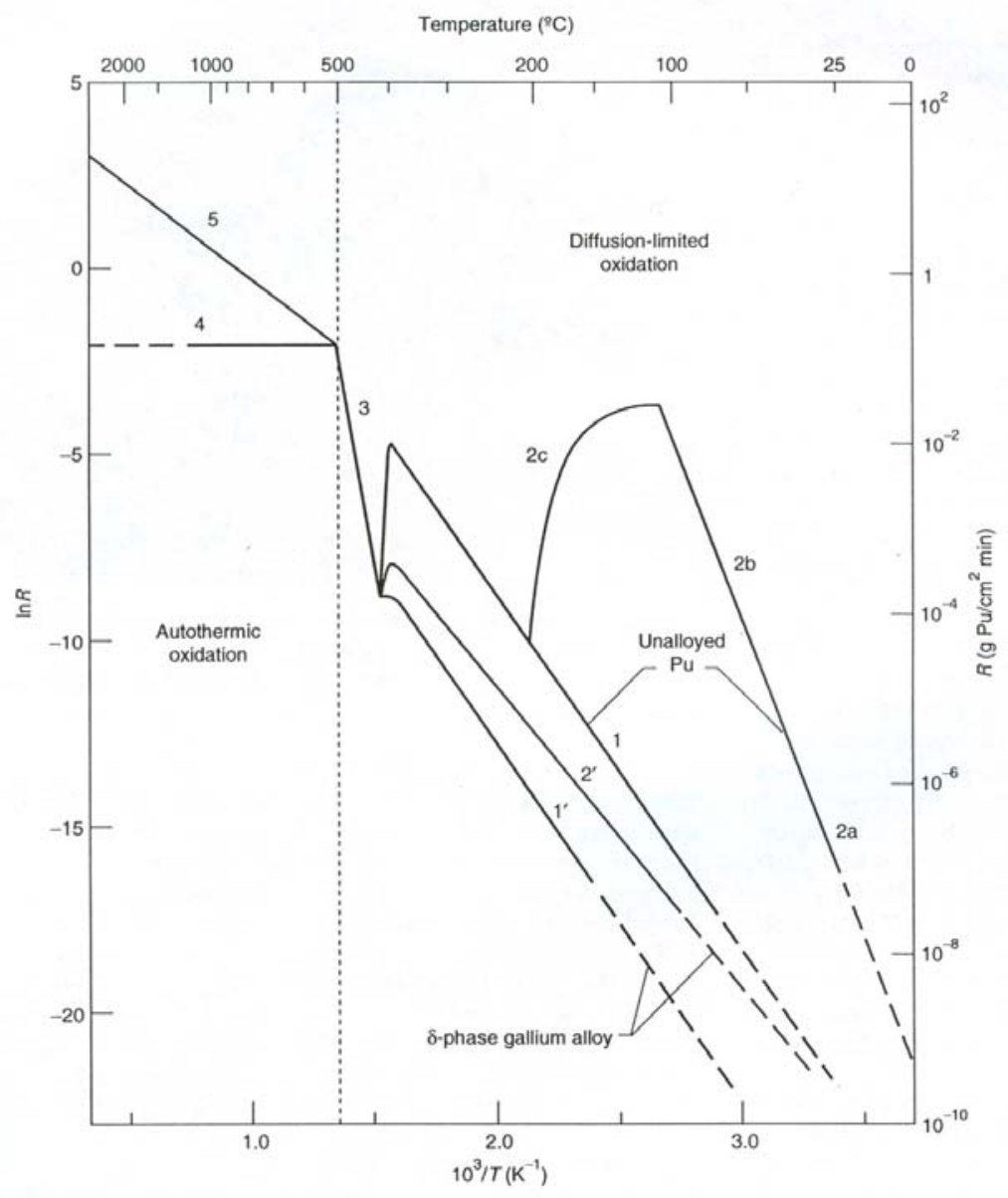

Figure 4: Arrhenius Curves for Oxidation of Plutonium in Dry Air (curve 1) and Water Vapor (curve 2a, $b$ and c). Gallium containing delta phase curves are denoted by the 1' and 2' labels. Curve 3 between $400^{\circ} \mathrm{C}$ and $500^{\circ} \mathrm{C}$ denotes the temperature range where the previous rates converge, prior to auto-ignition ${ }^{3}$. 
Table II: Oxidation Rate of Various Pure Metals in Dry Air or Oxygen

\begin{tabular}{|c|c|c|c|c|}
\hline Metal & $\begin{array}{l}\text { Temperature } \\
\left({ }^{\circ} \mathrm{C}\right)\end{array}$ & Relationship & Rate Constant & Reference \\
\hline $\mathrm{Pu}-\alpha$ phase & $200-400$ & Linear & $\mathrm{k}=289875 \exp (-8879.2 / \mathrm{T})^{*}$ & Haschke $^{3,4}$ \\
\hline $\mathrm{Pu}$ alloy- $\delta$ phase & $200-400$ & Linear & $\mathrm{k}=7886.6 \exp (-9090.5 / \mathrm{T})^{*}$ & Haschke $^{3,4}$ \\
\hline Pu autothermic & $500-660$ & Linear & $\mathrm{k}=0.14 \mathrm{~g} \mathrm{Pu} / \mathrm{cm}^{2} / \mathrm{hr}$ & Haschke $^{3,4}$ \\
\hline $\mathrm{Ti}$ & $600-1000$ & Parabolic & $\mathrm{k}=1.5 \mathrm{e} 9 \exp (-55000 / \mathrm{RT}) \dagger$ & Kofstad $^{7}$ \\
\hline $\mathrm{Zr}$ & $600-1000$ & Parabolic & $\mathrm{k}=6.6 \mathrm{e} 6 \exp (-36000 / \mathrm{RT}) \div$ & $\mathrm{Kofstad}^{7}$ \\
\hline $\mathrm{Hf}$ & $600-1000$ & Parabolic & $\mathrm{k}=6.6 \mathrm{e} 4 \mathrm{exp}(-36000 / \mathrm{RT}) \downarrow$ & Kofstad $^{7}$ \\
\hline $\mathrm{Ta}$ & $600-900$ & Linear $(1+2)$ & $\mathrm{k}=25.887 \exp (-5497.1 / \mathrm{T}) * \dagger$ & Kofstad $^{7}$ \\
\hline $\mathrm{Nb}$ & 700 & Linear & $\mathrm{k}=3.7 \mathrm{e}-2 \mathrm{~g} / \mathrm{cm} 2 / \mathrm{hr} \dagger$ & $\mathrm{Kofstad}^{7}$ \\
\hline $\mathrm{Ce}$ & 300 & Linear & $\mathrm{k}=7.0 \mathrm{e}-3 \mathrm{~g} / \mathrm{cm} 2 / \mathrm{hr}$ & Loriers $^{9}$ \\
\hline Th & $670-1270$ & Parabolic & $\mathrm{k}=9.2 \mathrm{e}-6 \exp (-24300 / \mathrm{RT}) \xi$ & $\begin{array}{l}\text { Gerds and } \\
\text { Mallett }^{10}\end{array}$ \\
\hline $\mathrm{U}$ & $600-1000$ & Linear & $\mathrm{k}=179.84 \exp (-4245.3 / \mathrm{T})^{*}$ & $\begin{array}{l}\text { Mouradian } \\
\text { and Baker }{ }^{13}\end{array}$ \\
\hline $\bar{U}$ & $300-800$ & Linear & $\mathrm{k}=33.472 \exp (-3357 / \mathrm{T})^{*}$ & $\begin{array}{l}\text { Isaacs and } \\
\text { Wanklyn }^{17}\end{array}$ \\
\hline
\end{tabular}

* units g metal $/ \mathrm{cm}^{2} / \mathrm{hr} \quad \$ \mathrm{mg}^{2} \mathrm{O}_{2} / \mathrm{cm}^{4} / \mathrm{min} \quad$ †oxidized in pure $\mathrm{O} 2 \quad \xi \mathrm{g}^{2} \mathrm{O}_{2} / \mathrm{cm}^{4} / \mathrm{s}$ 
WSRC-TR-2007-00471, Rev. 0

\section{Oxidation Rate of Several Metals}

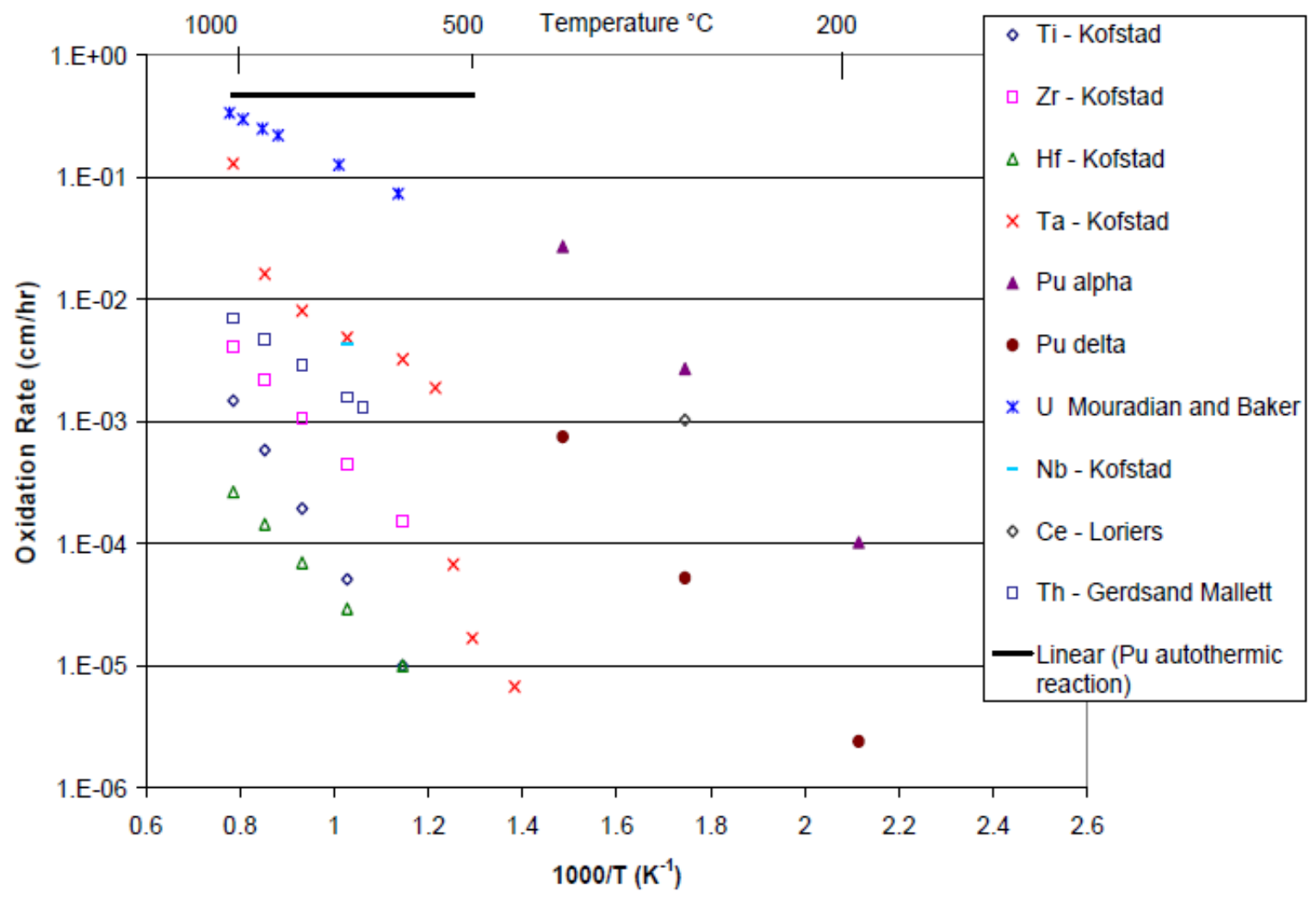

Figure 5: Oxidation Rates of Various Metals in Dry Air or Oxygen Compared to Plutonium (oxidation rate normalized for density of metallic substrate) 


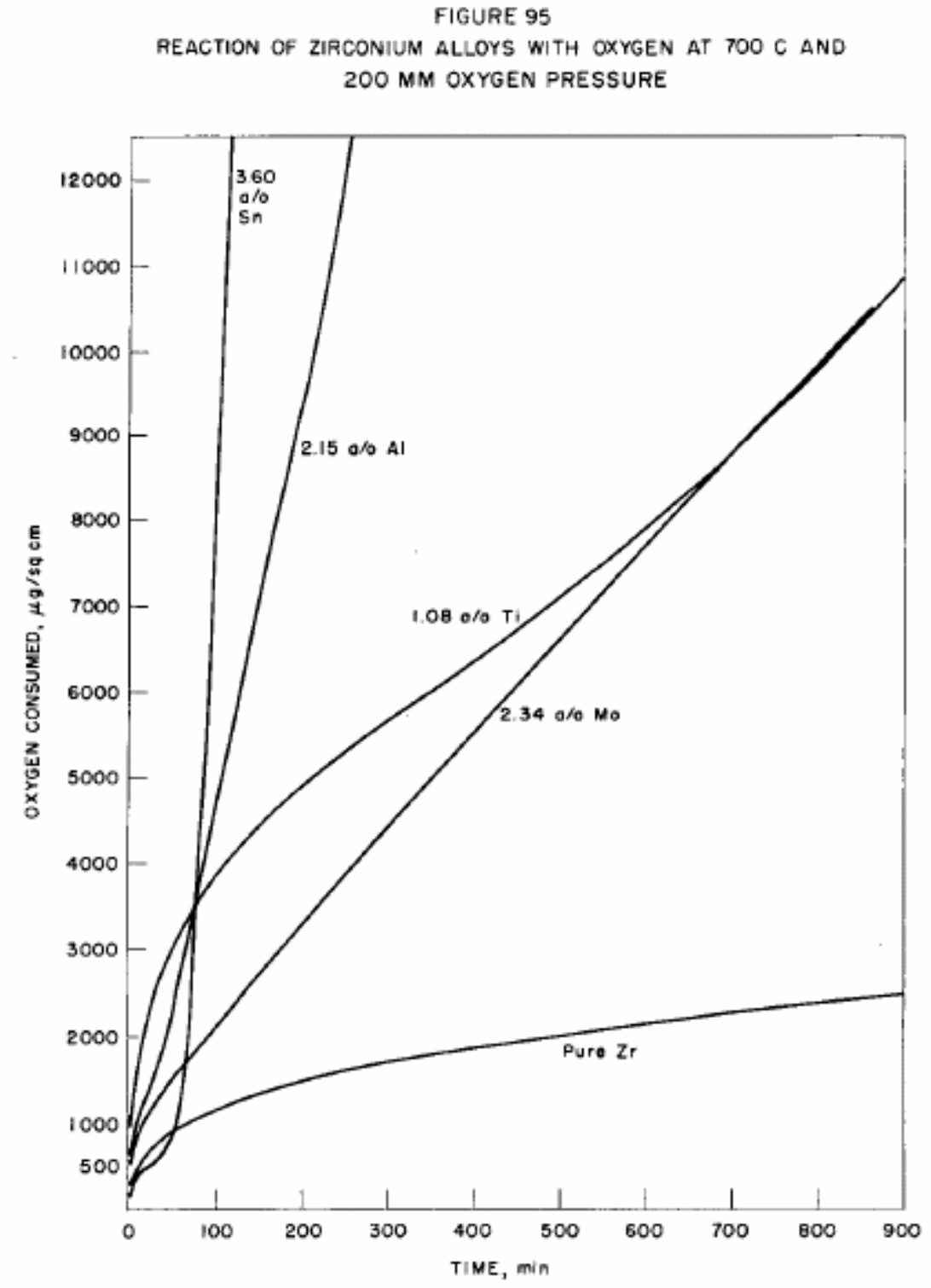

Figure 6: Effect of alloying addition on oxidation rate of zirconium (from Schnizlein et al.) the published rate for $3.6 \% \mathrm{Sn}$ is $292 \times 10^{-6} \mathrm{~g} / \mathrm{cm} 2 / \mathrm{min}$ at $700{ }^{\circ} \mathrm{C}$ which is roughly equivalent to $\mathrm{Pu}$ at $400{ }^{\circ} \mathrm{C}$

\subsection{SUMMARY AND RECOMMENDATIONS}

Surrogates to replace plutonium in the demonstration and validation of the $\mathrm{DMO}$ furnace for $\mathrm{PuD}$ were evaluated in terms of their metal/oxide characteristics and their oxidation behavior. A compilation of technical information was utilized to select the most promising candidate for a non-radioactive surrogate or one with minimal radioactivity. Several potential surrogates were evaluated by various criteria in order to select a suitable candidate for large scale demonstration. The structure of the plutonium metal/oxide interface was studied with respect to other metals. The oxidation rate data for plutonium oxidation kinetics were reviewed and rates for oxidation were compared with surrogates. The criteria used as a basis for recommendation was selected in order to provide a reasonable oxidation rate during the validation phase and are listed below. 
Oxidation Rate

Heat of Formation

Thermal Diffusivity of Metal
Pilling-Bedworth Relation

Nature of the oxide scale

The elements recommended as surrogates are listed in Table III, along with a summary of their properties and measured oxidation rates. The elements are ranked according to these 2 separate criteria. The first criterion is a combined measure of the elements deviation (\%) from the physical properties of the $\mathrm{Pu} / \mathrm{PuO} 2$ system. For example,

$$
\left.\% \text { deviation }=100 * \frac{(\mathrm{P}-\mathrm{B} \text { ratiosurrogate }-\mathrm{P}-\mathrm{B} \text { ratiopu }}{\mathrm{P}-\mathrm{B} \text { ratioPu }}\right)
$$

The second is according to the similarity of their measured oxidation rates. With respect to physical properties, cerium and titanium show the best similarity to the $\mathrm{Pu} / \mathrm{PuO} 2$ system. With respect to measured oxidation rates, uranium, zirconium and tantalum (shaded in yellow) yield the best overall oxidation rates. Titanium, hafnium, thorium and niobium (shaded in blue) are alternates because they behave similarly to the first three surrogates. Cerium was noted for its similar oxidation rate at low temperatures but will ignite at $320^{\circ} \mathrm{C}$. In most cases, oxidation rates that are lower would result in a conservative demonstration of the process. In every case, these metals have limitations as surrogates. All of these elements will ignite at elevated temperatures (although not to the extent of $\mathrm{Pu}$ ). Zirconium, titanium and hafnium must be of commercial purity or alloyed in order to initiate breakaway oxidation. Tantalum should not be used below $500^{\circ} \mathrm{C}$ and niobium should not be used between 650 and $800^{\circ} \mathrm{C}$, as the oxide scales are known to transition into a protective scale. Of course, uranium, thorium and hafnium are radioactive and have limitations associated with their use.

\begin{tabular}{|c|c|c|c|c|c|c|c|c|c|c|}
\hline \multicolumn{5}{|c|}{ Metal/Oxide Properties } & \multicolumn{6}{|c|}{ Oxidation Rate } \\
\hline \multirow[t]{2}{*}{ Element } & \multirow[t]{2}{*}{$\begin{array}{l}\text { P-B } \\
\text { Ratio } \\
\text { (\%dev) }\end{array}$} & \multirow[t]{2}{*}{$\begin{array}{l}\text { Heat of } \\
\text { Form. } \\
\text { (\%dev) }\end{array}$} & \multirow{2}{*}{$\begin{array}{l}\text { Thermal } \\
\text { Diff. of } \\
\text { Metal } \\
\text { (\%dev) }\end{array}$} & \multirow[t]{2}{*}{ 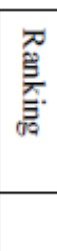 } & \multicolumn{2}{|c|}{$\begin{array}{l}\text { Temperature to } \\
\text { match } \delta-\mathrm{Pu} \\
\text { oxidation rate }\end{array}$} & \multirow{2}{*}{$\begin{array}{l}\text { Ignition } \\
\text { Temperature } \\
\text { (bulk in } \\
\text { Air } / \mathrm{O}_{2} \text { ) }\end{array}$} & \multirow[t]{2}{*}{$\begin{array}{l}\text { Radio- } \\
\text { activity } \\
(\mathrm{uCi} / \mathrm{g})\end{array}$} & \multirow[t]{2}{*}{$\begin{array}{l}\text { NFPA Health, } \\
\text { Flammability, } \\
\text { Reactivity }\end{array}$} & \multirow[t]{2}{*}{ 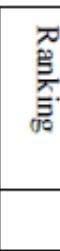 } \\
\hline & & & & & (a) $400^{\circ} \mathrm{C}$ & (a) $500^{\circ} \mathrm{C}$ & & & & \\
\hline $\mathrm{Pu}-239^{18}$ & $* * *$ & **** & $* * *$ & & $* * *$ & $* * *$ & $\sim 500^{\circ} \mathrm{C}$ & $0.062^{*}$ & $\mathrm{U}, 3,2$ & \\
\hline $\mathrm{U}-238^{19}$ & $\begin{array}{l}+20\left(\mathrm{UO}_{2}\right) \\
60\left(\mathrm{U}_{3} \mathrm{O}_{8}\right)\end{array}$ & $\begin{array}{l}+8\left(\mathrm{UO}_{2}\right) \\
13\left(\mathrm{U}_{3} \mathrm{O}_{8}\right)\end{array}$ & +202 & 5 & $\begin{array}{l}250- \\
300^{\circ} \mathrm{C}\end{array}$ & $1000^{\circ} \mathrm{C}$ & $\sim 600^{\circ} \mathrm{C}$ & $0.33^{*}$ & $3,3,2$ & 1 \\
\hline $\mathrm{Zr}^{20}$ & -2 & +3 & +203 & 4 & $550^{\circ} \mathrm{C}$ & $\begin{array}{l}717^{\circ} \mathrm{C}- \\
1000^{\circ} \mathrm{C}\end{array}$ & $>350^{\circ} \mathrm{C} \dagger$ & & $2,4,2$ & 2 \\
\hline $\mathrm{Ta}^{21}$ & +55 & 0 & +500 & 7 & $550^{\circ} \mathrm{C}$ & $\begin{array}{l}>1000^{\circ} \\
\mathrm{C}\end{array}$ & $1250^{\circ} \mathrm{C}$ & & $1,0,0$ & 3 \\
\hline $\mathrm{Nb}^{22}$ & +68 & -10 & +472 & 6 & $550^{\circ} \mathrm{C}$ & $\begin{array}{l}>1000^{\circ} \\
\mathrm{C}\end{array}$ & N/A & & $1,1,0$ & 4 \\
\hline $\mathrm{Hf}^{23}$ & 2 & +8 & +190 & 3 & $750^{\circ} \mathrm{C}$ & $\begin{array}{l}>1000^{\circ} \\
\mathrm{C}\end{array}$ & N/A & $*$ & $0,0,0$ & 6 \\
\hline $\mathrm{Ti}^{24}$ & +12 & -13 & +125 & 2 & $700^{\circ} \mathrm{C}$ & & $1200^{\circ} \mathrm{C}$ & & $1,0,0$ & 5 \\
\hline Th- $232^{25}$ & -15 & +17 & +846 & 8 & $600^{\circ} \mathrm{C}$ & $\begin{array}{l}>1000^{\circ} \\
\mathrm{C}\end{array}$ & $500^{\circ} \mathrm{C}$ & $0.1^{*}$ & & 7 \\
\hline $\mathrm{Ce}^{26}$ & -27 & -7 & +110 & 1 & $300^{\circ} \mathrm{C}$ & & $350^{\circ} \mathrm{C}+$ & & $1,1,2$ & 8 \\
\hline
\end{tabular}

Table III: Summary of Potential Surrogates for Plutonium Oxidation 


\subsection{REFERENCES}

${ }^{1}$ Korinko, Paul, Direct Metal Oxidation Furnace - Pu / Basket Interaction, Technical Memorandum \#SRNL-MST-2007-00008,

${ }^{2}$ Hilton, B. A., "Review of Oxidation Rates of DOE Spent Nuclear Fuel, Part I Metallic Fuel," ANL 00/24, Argonne National Laboratory, November, 2000.

${ }^{3}$ Haschke, J. M., Allen, T. H. and Martz, J. C., "Oxidation Kinetics of Plutonium in Air: Consequences for Environmental Dispersal," Report \# LA-UR-97-2592, Los Alamos National Laboratory, July, 1997.

${ }^{4}$ Haschke, J. M., Allen, T. H. and Morales, L. A., "Surface and Corrosion Chemistry of Plutonium," Los Alamos Science, Number 26, 2000, p. 253.

5 J. E. Laurinet, "Analysis of Burning of Plutonium Alloys in FB-Line Furnaces," Calculation Note XCLC-F-00429

${ }^{6}$ Kolman, D. G., “Direct Metal Oxidation Furnace Description,” Los Alamos Report \#LA-UR-02-6627.

${ }^{7}$ High Temperature Oxidation of Metals, Per Kofstad, John Wiley and Sons, 1966

${ }^{8}$ Oxidation of Metals and Alloys, Kubaschewski and Hopkins, Academic Press Inc, Publishers London 1962

${ }^{9}$ Loriers, J. Rev Metall. 49 (1952) 801, 883

${ }^{10}$ Gerds, A. F. and Mallett, M. W. , J. Electrochemical Soc. 101(1954) 171, 175

${ }^{11}$ Duncan, A. J. and Hathcock, D. J., "Uranium Metal to Oxide Conversion by Air Oxidation-Process Development," Technical Report \# WSRC-TR-2005-00440 Rev. 0, October, 2005

${ }^{12}$ Leibowitz, L. et al., "Burning Velocities of Uranium and Zirconium in Air," Nuclear Science and Engineering 15, 395 (1963).

${ }^{13}$ Mouradian, E. M. and Baker, L. "Burning Temperature of Uranium and Zirconium in Air," Nuclear Science and Engineering 15, 388 (1963).

${ }^{14}$ Bagley, K. Q. and Oliver, D. S., "The Oxidation of Uranium in Air," R \&DB (D) TN-32, United Kingdom Atomic Energy Authority, Risley, Warrington, Lancashire, UK, May, 1953.

${ }^{15}$ Schnizlein, Ignition Behavior and Kinetics of Oxidation of the Reactor Metals, Uranium, Zirconium, Plutonium and Thorium, and Binary Alloys of each, Report \# ANL-5974,

${ }^{16} \mathrm{P}$. Korinko, private communication

${ }^{17}$ Isaacs, J. W. and Wanklyn, J. N., "The reaction of Uranium with Air at High Temperatures," AERE-R 3559, Atomic Energy Research Group, United Kingdom, December 1960

${ }^{18}$ Plutonium Metal Materials Safety Data Sheet \# 25325, New Bruswick Laboratory, U. S. DOE, Argonne, IL, November 17, 1994.

${ }^{19}$ Uranium Metal Materials Safety Data Sheet \# 13102, Johnson Matthey Company, Ward Hill, MA, January, 1991

${ }^{20}$ Zirconium Metal Materials Safety Data Sheet \# 35376, Alfa Aesar, Johnson Matthey Company, Ward Hill, MA, August, 2002.

${ }^{21}$ Tantalum Metal Materials Safety Data Sheet \# 33820, Cabot Performance Materials, Boyertown, PA, December, 2000

${ }^{22}$ Niobium Metal Materials Safety Data Sheet \#10771, Aldrich Chemical., Milwaukee, WI, December, 1990.

${ }^{23}$ Hafnium Metal Materials Safety Data Sheet, CAS \# 7440-58-6, Electronic Space Products International, Ashland, OR, September, 1996

${ }^{24}$ Titanium Metal Materials Safety Data Sheet, CAS \# 7440-32-6, Electronic Space Products International, Ashland, OR, November, 2002

${ }^{25}$ Thorium Metal Materials Safety Data Sheet \#26642, A. D. McKay Inc., Red Hook, NY, May 1998.

${ }^{26}$ Cerium Metal Materials Safety Data Sheet \#23050, Atomergic Chemetals Corp., July, 1990. 
WSRC-TR-2007-00471, Rev. 0

Page A1

January 2008

Table AI: Raw Data for Metal-Oxide Systems to be Evaluated as Potential Surrogates (Table I).

\begin{tabular}{|c|c|c|c|c|c|c|c|c|c|c|c|c|c|c|c|c|c|c|}
\hline $\begin{array}{l}\text { Coeff. of } \\
\text { Thermal } \\
\text { Exp. X10-6 } \\
\text { IK }\end{array}$ & $\begin{array}{l}\text { Thermal } \\
\text { diff } \mathrm{cm} 2 / \mathrm{s}\end{array}$ & dev & $\begin{array}{l}\text { Heat } \\
\text { Capacity } \\
\text { Cp J/gk }\end{array}$ & $\begin{array}{l}\text { Themal } \\
\text { Cond. } \\
\text { W/cmk }\end{array}$ & Metal & $\begin{array}{l}\text { Overall } \\
\% \text { dev }\end{array}$ & $\begin{array}{l}\text { mol. } \\
\text { weight m }\end{array}$ & $\begin{array}{l}\text { density } \\
\text { g/cm3 }\end{array}$ & Oxide & $\begin{array}{l}\text { mol. } \\
\text { weight M }\end{array}$ & Density & $\begin{array}{l}\text { number } \\
\text { of metal } \\
\text { atomsl } \\
\text { mole }\end{array}$ & $\begin{array}{l}\text { Pillings- } \\
\text { Bedworth } \\
\text { Ratio }\end{array}$ & \%dev & & $\begin{array}{l}\text { Heat of } \\
\text { Formation } \\
\text { kcal/mol }\end{array}$ & $\begin{array}{l}\text { Heat of } \\
\text { Formation/ } \\
\text { mole metal } \\
\mathrm{KJ} / \mathrm{mol}\end{array}$ & $\%$ dev \\
\hline-8.6 & 0.041 & 0.0 & 0.14 & 0.0921 & Pu delta & 0 & 239.0 & J $\quad 15.92$ & PuO2 & 274.0 & 11.46 & & $\begin{array}{ll}1 & 1.59\end{array}$ & & 0 & -251.0 & -1050.9 & 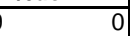 \\
\hline-7.6 & 0.041 & 0.0 & 0.14 & 0.0921 & & 7 & 239.0 & 15.92 & Pu2O3 & 536.0 & 10.5 & & 1.70 & & 7 & & & \\
\hline 46.8 & 0.024 & -41.3 & 0.14 & 0.0674 & Pu alpha & 48 & 239.0 & 19.84 & PuO2 & 274.0 & 11.46 & & 1.98 & & 25 & -251.0 & -1050.9 & 0 \\
\hline 47.8 & 0.024 & -41.3 & 0.14 & 0.0674 & & 53 & 239.0 & 19.84 & Pu2O3 & 536.0 & 10.5 & & 2.12 & & 33 & & & \\
\hline 13.9 & 0.125 & 202.3 & 0.116 & 0.276 & $u$ & 204 & 238.0 & 19.05 & UO2 & 270.0 & 10.96 & & 1.97 & & 24 & -270.0 & -1130.4 & 8 \\
\hline 14.9 & 0.125 & 202.3 & 0.116 & 0.276 & & 215 & 238.0 & 19.05 & U308 & 842.1 & 8.3 & & 2.71 & & 70 & -299.3 & -1253.2 & 19 \\
\hline 15.9 & 0.125 & 202.3 & 0.116 & 0.276 & & 225 & 238.0 & 19.05 & UO3 & 286.0 & 7.29 & & 3.14 & & 98 & -302.0 & -1264.4 & 20 \\
\hline 5.7 & 0.125 & 203.1 & 0.278 & 0.227 & $z r$ & 203 & 91.2 & 6.52 & $\mathrm{ZrO2}$ & 123.2 & 5.68 & & 1.55 & & -2 & -258.2 & -1081.0 & 3 \\
\hline 6.3 & 0.247 & 498.7 & 0.14 & 0.575 & $\mathrm{Ta}$ & 502 & 181.0 & 16.6 & Ta2O5 & 441.9 & 8.2 & & 2.47 & & 55 & -250.0 & -1046.5 & 0 \\
\hline 5.9 & 0.120 & 190.4 & 0.144 & 0.23 & $\mathrm{Hf}$ & 191 & 178.5 & 13.31 & $\mathrm{HfO} 2$ & 210.5 & 9.68 & & 1.62 & & 2 & -271.5 & -1136.7 & 8 \\
\hline 8.6 & 0.093 & 125.1 & 0.522 & 0.219 & $\mathrm{Ti}$ & 126 & 47.9 & 4.51 & TiO2 & 79.9 & 4.23 & & 1.78 & & 12 & -218.0 & -912.7 & -13 \\
\hline 7.3 & 0.236 & 472.2 & 0.265 & 0.537 & $\mathrm{Nb}$ & 477 & 92.9 & 8.57 & $\mathrm{Nb2O5}$ & 265.8 & 4.6 & & 2.67 & & 68 & & -949.75 & -10 \\
\hline 11 & 0.391 & 846.5 & 0.118 & 0.54 & Th & 847 & 232.0 & 11.7 & ThO2 & 264.0 & 9.86 & & 1.35 & & -15 & -292.0 & -1226.4 & 17 \\
\hline 6.3 & 0.087 & 110.1 & 0.192 & 0.113 & $\mathrm{Ce}$ & 113 & 140.1 & 6.78 & $\mathrm{CeO} 2$ & 172.1 & 7.132 & & 1.17 & & -27 & -233.0 & -975.5 & -7 \\
\hline 11.8 & 0.227 & 449.9 & 0.449 & 0.802 & $\mathrm{Fe}$ & 456 & 55.9 & 7.86 & $\mathrm{FeO}$ & 71.9 & 5.7 & & 1.77 & & 12 & -63.7 & -266.7 & -75 \\
\hline 12.8 & 0.227 & 449.9 & 0.449 & 0.802 & & 455 & 55.9 & 7.86 & $\mathrm{Fe} 2 \mathrm{O} 3$ & 159.7 & 5.24 & & 2.14 & & 35 & -98.3 & -411.4 & -61 \\
\hline 13.8 & 0.227 & 449.9 & 0.449 & 0.802 & & 458 & 55.9 & 7.86 & $\mathrm{Fe} 304$ & 231.5 & 5.18 & & 2.10 & & 32 & -45.3 & -189.5 & -82 \\
\hline 16.5 & 1.171 & 2733.1 & 0.384 & $\begin{array}{r}4.01 \\
\end{array}$ & $\mathrm{Cu}$ & 2734 & 63.5 & 8.92 & CuO & 79.5 & 6.4 & & 1.74 & & 10 & -37.1 & -155.3 & -85 \\
\hline 17.5 & 1.171 & 2733.1 & 0.384 & 4.01 & & 2735 & 63.5 & 8.92 & Cu2O & 143.1 & 6 & & 1.67 & & 5 & -19.9 & -83.4 & -92 \\
\hline 13.4 & 0.229 & 454.2 & 0.445 & 0.907 & $\mathrm{Ni}$ & 461 & 58.7 & 8.9 & $\mathrm{NiO}$ & 74.7 & 6.67 & & 1.70 & & 7 & -58.4 & -244.5 & -77 \\
\hline 0.421 & 0.267 & 545.9 & 0.421 & & Co & 551 & 58.9 & 8.9 & Co3O4 & 240.8 & 6.07 & & 2.00 & & 26 & -210.0 & -293.1 & -72 \\
\hline 1.421 & 0.267 & 545.9 & 0.421 & 1 & & 551 & 58.9 & 8.9 & $\mathrm{CoO}$ & 74.9 & 6.45 & & 1.75 & & 10 & -57.2 & -239.5 & -77 \\
\hline
\end{tabular}


Table AII: Raw Data for Oxidation Rates of Various Metals in Dry Air or Oxygen Compared to Plutonium (Figure 5)

\begin{tabular}{|c|c|c|c|c|c|c|c|c|c|}
\hline \multirow{5}{*}{\begin{tabular}{|l|} 
\\
Pu \\
autothermic \\
reaction
\end{tabular}} & \multirow[b]{2}{*}{ T deg. $C$} & \multirow[b]{2}{*}{$1 / \mathrm{T}(\mathrm{K})$} & \multirow[b]{2}{*}{$\exp (-Q / R T)$} & \multirow[b]{2}{*}{ A } & \multirow{2}{*}{\begin{tabular}{|l|} 
Rate Constant \\
mg2O2/ \\
cm4/min
\end{tabular}} & \multirow{2}{*}{\begin{tabular}{|l}
$1 \mathrm{hr}$ cycle \\
$\mathrm{g} / \mathrm{cm} 2$
\end{tabular}} & \multirow{2}{*}{\begin{tabular}{|l|} 
Rate Constant \\
g metal/ \\
cm $2 /$ min
\end{tabular}} & \multirow{2}{*}{\begin{tabular}{|l|}
$1 \mathrm{hr}$ cycle \\
$\mathrm{g} / \mathrm{cm} 2$ \\
\end{tabular}} & \multirow{2}{*}{\begin{tabular}{|l} 
rate/density \\
$\mathrm{cm} / \mathrm{hr}$
\end{tabular}} \\
\hline & & & & & & & & & \\
\hline & 500 & 1.29 & & & & & 0.13 & $7.80 \mathrm{E}+00$ & 4.73E-01 \\
\hline & 660 & 1.07 & & & & & 0.13 & $7.80 \mathrm{E}+00$ & 4.73E-01 \\
\hline & 1000 & 0.79 & & & & & 0.13 & $7.80 \mathrm{E}+00$ & 4.73E-01 \\
\hline \multirow[t]{3}{*}{ Pu alpha } & 200 & 2.11 & & & & & 3.40E-05 & $2.04 \mathrm{E}-03$ & $1.03 \mathrm{E}-04$ \\
\hline & 300 & 1.75 & & & & & $9.00 \mathrm{E}-04$ & $5.40 \mathrm{E}-02$ & $2.72 \mathrm{E}-03$ \\
\hline & 400 & 1.49 & & & & & $9.00 \mathrm{E}-03$ & $5.40 \mathrm{E}-01$ & 2.72E-02 \\
\hline \multirow[t]{3}{*}{ Pu delta } & 200 & 2.11 & & & & & $6.40 \mathrm{E}-07$ & 3.84E-05 & $2.41 \mathrm{E}-06$ \\
\hline & 300 & 1.75 & & & & & $1.40 \mathrm{E}-05$ & 8.40E-04 & $5.28 \mathrm{E}-05$ \\
\hline & 400 & 1.49 & & & & & 2.00E-04 & $1.20 \mathrm{E}-02$ & 7.54E-04 \\
\hline \multirow[t]{6}{*}{$\begin{array}{l}\text { U Mouradian } \\
\text { and Baker }\end{array}$} & 607 & 1.14 & & & 4.3 & $2.58 \mathrm{E}-01$ & $2.40 \mathrm{E}-02$ & $1.44 \mathrm{E}+00$ & 7.38E-02 \\
\hline & 717 & 1.01 & & & 7.4 & 4.44E-01 & 4.13E-02 & $2.48 \mathrm{E}+00$ & $1.27 \mathrm{E}-01$ \\
\hline & 862 & 0.88 & & & 12.9 & 7.74E-01 & 7.20E-02 & $4.32 E+00$ & 2.21E-01 \\
\hline & 907 & 0.85 & & & 14.6 & 8.76E-01 & 8.15E-02 & $4.89 E+00$ & 2.51E-01 \\
\hline & 967 & 0.81 & & & 17.5 & $1.05 E+00$ & $9.76 \mathrm{E}-02$ & $5.86 \mathrm{E}+00$ & 3.00E-01 \\
\hline & 1012 & 0.78 & & & 19.7 & $1.18 \mathrm{E}+00$ & $1.10 \mathrm{E}-01$ & $6.59 E+00$ & 3.38E-01 \\
\hline \multirow{6}{*}{$\begin{array}{l}\text { U Isaacs and } \\
\text { Wanklyn }\end{array}$} & & & & & & & & & \\
\hline & 300 & 1.75 & & & 0.18 & $1.08 \mathrm{E}-02$ & $1.01 \mathrm{E}-03$ & 6.05E-02 & 3.10E-03 \\
\hline & 360 & 1.58 & & & 0.99 & 5.96E-02 & $5.55 \mathrm{E}-03$ & 3.33E-01 & $1.71 \mathrm{E}-02$ \\
\hline & 503 & 1.29 & & & 1.17 & 7.05E-02 & $6.55 \mathrm{E}-03$ & 3.93E-01 & $2.02 \mathrm{E}-02$ \\
\hline & 610 & 1.13 & & & 1.81 & $1.08 \mathrm{E}-01$ & $1.01 \mathrm{E}-02$ & $6.05 E-01$ & $3.10 \mathrm{E}-02$ \\
\hline & 710 & 1.02 & & & 3.614 & 2.17E-01 & 2.02E-02 & $1.21 \mathrm{E}+00$ & $6.20 \mathrm{E}-02$ \\
\hline \multirow[t]{5}{*}{ Ti - Kofstad } & 600 & 1.15 & $1.52 \mathrm{E}-14$ & $1.50 \mathrm{E}+09$ & $2.28 \mathrm{E}-05$ & $3.70 \mathrm{E}-05$ & $3.41 \mathrm{E}-11$ & $4.52 \mathrm{E}-05$ & $1.00 \mathrm{E}-05$ \\
\hline & 700 & 1.03 & $3.99 \mathrm{E}-13$ & $1.50 \mathrm{E}+09$ & 5.99E-04 & 1.90E-04 & 8.97E-10 & 2.32E-04 & 5.14E-05 \\
\hline & 800 & 0.93 & $5.71 \mathrm{E}-12$ & $1.50 \mathrm{E}+09$ & 8.57E-03 & 7.17E-04 & $1.28 \mathrm{E}-08$ & 8.77E-04 & $1.95 \mathrm{E}-04$ \\
\hline & 900 & 0.85 & 5.19E-11 & $1.50 \mathrm{E}+09$ & 7.79E-02 & $2.16 \mathrm{E}-03$ & 1.17E-07 & 2.64E-03 & 5.86E-04 \\
\hline & 1000 & 0.79 & 3.34E-10 & $1.50 \mathrm{E}+09$ & 5.01E-01 & 5.48E-03 & 7.49E-07 & 6.70E-03 & $1.49 \mathrm{E}-03$ \\
\hline \multirow[t]{5}{*}{ Zr - Kofstad } & 600 & 1.15 & $9.02 \mathrm{E}-10$ & $6.60 \mathrm{E}+06$ & 5.95E-03 & $5.98 \mathrm{E}-04$ & $1.70 \mathrm{E}-08$ & $1.01 \mathrm{E}-03$ & $1.55 \mathrm{E}-04$ \\
\hline & 700 & 1.03 & 7.67E-09 & $6.60 \mathrm{E}+06$ & 5.06E-02 & $1.74 \mathrm{E}-03$ & $1.44 \mathrm{E}-07$ & $2.94 \mathrm{E}-03$ & 4.51E-04 \\
\hline & 800 & 0.93 & 4.37E-08 & $6.60 E+06$ & 2.89E-01 & 4.16E-03 & 8.23E-07 & 7.03E-03 & $1.08 \mathrm{E}-03$ \\
\hline & 900 & 0.85 & $1.85 \mathrm{E}-07$ & $6.60 \mathrm{E}+06$ & $1.22 \mathrm{E}+00$ & 8.57E-03 & $3.49 E-06$ & $1.45 \mathrm{E}-02$ & $2.22 \mathrm{E}-03$ \\
\hline & 1000 & 0.79 & $6.27 \mathrm{E}-07$ & $6.60 \mathrm{E}+06$ & $4.14 \mathrm{E}+00$ & 1.58E-02 & $1.18 \mathrm{E}-05$ & $2.66 \mathrm{E}-02$ & $4.08 \mathrm{E}-03$ \\
\hline \multirow[t]{5}{*}{ Hf - Kofstad } & 600 & 1.15 & $9.02 \mathrm{E}-10$ & $6.00 \mathrm{E}+04$ & $5.41 \mathrm{E}-05$ & $5.70 \mathrm{E}-05$ & $3.02 \mathrm{E}-10$ & $1.35 \mathrm{E}-04$ & $1.01 \mathrm{E}-05$ \\
\hline & 700 & 1.03 & 7.67E-09 & $6.00 E+04$ & 4.60E-04 & 1.66E-04 & 2.57E-09 & $3.92 \mathrm{E}-04$ & 2.95E-05 \\
\hline & 800 & 0.93 & 4.37E-08 & $6.00 E+04$ & $2.62 \mathrm{E}-03$ & 3.97E-04 & $1.46 \mathrm{E}-08$ & 9.37E-04 & 7.04E-05 \\
\hline & 900 & 0.85 & $1.85 \mathrm{E}-07$ & $6.00 E+04$ & 1.11E-02 & 8.17E-04 & $6.21 \mathrm{E}-08$ & 1.93E-03 & 1.45E-04 \\
\hline & 1000 & 0.79 & $6.27 \mathrm{E}-07$ & $6.00 \mathrm{E}+04$ & 3.76E-02 & 1.50E-03 & $2.10 \mathrm{E}-07$ & 3.55E-03 & 2.67E-04 \\
\hline $\begin{array}{l}\text { Th - Gerdsand } \\
\text { Mallett }\end{array}$ & 670 & 1.06 & $2.23 \mathrm{E}-06$ & $9.20 \mathrm{E}-06$ & $1.23 \mathrm{E}-03$ & $2.72 \mathrm{E}-04$ & 8.92E-09 & 7.31E-04 & $6.24 \mathrm{E}-05$ \\
\hline & 700 & 1.03 & 3.33E-06 & $9.20 \mathrm{E}-06$ & $1.84 \mathrm{E}-03$ & $3.32 \mathrm{E}-04$ & 1.33E-08 & 8.94E-04 & 7.63E-05 \\
\hline & 800 & 0.93 & $1.08 \mathrm{E}-05$ & $9.20 \mathrm{E}-06$ & $5.95 \mathrm{E}-03$ & $5.98 \mathrm{E}-04$ & $4.31 \mathrm{E}-08$ & $1.61 \mathrm{E}-03$ & 1.37E-04 \\
\hline & 900 & 0.85 & $2.86 \mathrm{E}-05$ & $9.20 \mathrm{E}-06$ & $1.58 \mathrm{E}-02$ & $9.73 \mathrm{E}-04$ & 1.14E-07 & $2.62 \mathrm{E}-03$ & 2.24E-04 \\
\hline & 1000 & 0.79 & $6.50 \mathrm{E}-05$ & $9.20 \mathrm{E}-06$ & $3.59 \mathrm{E}-02$ & 1.47E-03 & 2.60E-07 & 3.95E-03 & 3.37E-04 \\
\hline Ta-Kofstad & 450 & 1.38 & & & $4.17 \mathrm{E}-07$ & $2.50 \mathrm{E}-05$ & $1.88 \mathrm{E}-06$ & $1.13 \mathrm{E}-04$ & $6.78 \mathrm{E}-06$ \\
\hline & 500 & 1.29 & $6.20 \mathrm{E}-08$ & & $1.04 \mathrm{E}-06$ & $6.25 \mathrm{E}-05$ & $4.71 \mathrm{E}-06$ & 2.83E-04 & $1.69 E-05$ \\
\hline & 525 & 1.25 & $1.04 \mathrm{E}-07$ & & 4.2E-06 & 2.50 E-04 & $1.88 \mathrm{E}-05$ & 1.13E-03 & $6.78 \mathrm{E}-05$ \\
\hline & 550 & 1.22 & & & 1.17E-04 & 7.00E-03 & $5.28 \mathrm{E}-04$ & 3.17E-02 & 1.90E-03 \\
\hline & 600 & 1.15 & $1.26 \mathrm{E}-10$ & 1.40E-04 & 2.00E-04 & $1.20 \mathrm{E}-02$ & 9.05E-04 & 5.43E-02 & $3.25 \mathrm{E}-03$ \\
\hline & 700 & 1.03 & 1.31E-09 & 1.40E-04 & 3.00E-04 & 1.80E-02 & 1.36E-03 & 8.14E-02 & 4.88E-03 \\
\hline & 800 & 0.93 & 8.83E-09 & 1.40E-04 & 5.00E-04 & $3.00 \mathrm{E}-02$ & $2.26 \mathrm{E}-03$ & 1.36E-01 & 8.13E-03 \\
\hline & 900 & 0.85 & 4.29E-08 & 1.40E-04 & 1.00E-03 & $6.00 \mathrm{E}-02$ & 4.52E-03 & 2.71E-01 & 1.63E-02 \\
\hline & 1000 & 0.79 & $1.63 \mathrm{E}-07$ & 1.40E-04 & $8.00 \mathrm{E}-03$ & 4.80E-01 & $3.62 \mathrm{E}-02$ & $2.17 \mathrm{E}+00$ & $1.30 \mathrm{E}-01$ \\
\hline Nb - Kofstad & 600 & 1.15 & & & & & & & \\
\hline & 700 & 1.03 & & & 2.67E-04 & 1.60E-02 & 6.19E-04 & $3.72 \mathrm{E}-02$ & 4.34E-03 \\
\hline Ce - Loriers & 300 & 1.75 & & & & & $1.17 \mathrm{E}-04$ & $7.02 \mathrm{E}-03$ & $1.04 \mathrm{E}-03$ \\
\hline
\end{tabular}

